\title{
Local Responses to Macro Development Policies and Their Effects on Rural System in China's Mountainous Regions: The Case of Shuanghe Village in Sichuan Province
}

\author{
LI Yu-rui, LIU Yan-sui, LONG Hua-lou, WANG Jie-yong* \\ Institute of Geographic Sciences and Natural Resources Research, Chinese Academy of Sciences, Beijing 100101, China \\ Key Laboratory of Regional Sustainable Development Modeling, Chinese Academy of Sciences, Beijing 10o1o1, China \\ *Corresponding author, e-mail: wjy@igsnrr.ac.cn; First author,e-mail: lyr20o8@163.com
}

(C) Science Press and Institute of Mountain Hazards and Environment, CAS and Springer-Verlag Berlin Heidelberg 2013

\begin{abstract}
China has promulgated a series of policies including the Western Development Program, the Grain for Green Project, agricultural support policies and building a new countryside strategy to eliminate east-west differences and urban-rural disparities since the late 1990s. This paper gives a holistic examination on local responses to the four typical macro socio-economic development policies and their effects on rural system based on a case study of a mountainous village in southern Sichuan Province. The results showed that the policies have not moved the case study village from its historically marginal status. To some extent, its socio-economic situation might have been worsened by accelerated outmigration of the youth, loss of agricultural land due to afforestation and industrial plants, increased fire hazard due to afforestation and reforestation, increased environmental pollution due to industrial enterprises attracted to the village and a steep decline in agricultural production due to loss of and inefficient use of cultivated land. Factors causing local villages' dilemmas include the nonuniformity of actors' objectives, finiteness of villagers' abilities, and the imperfect incentive and restraint mechanism for local government's activities under existing policy framework composed of uncoordinated one-size-fitsall policies. We suggest that China's rural policy in the new period should gradually shift from a sectoral to a place-based one, from top-down incentives to the development of bottom-up projects, and fully recognize the diversity of rural space, so as to lift local
\end{abstract}

Received: 21 September 2012

Accepted: 13 March 2013 capacities and make good use of the knowledge shared by different actors. Moreover, it is also necessary to integrate the various sectoral policies, and improve the interministerial and interdepartmental coordination of rural policies at regional and local levels.

Key words: Local responses; Western Development Program; Grain for Green Project; Agricultural support policies; Building new countryside; Rural policy evaluation

\section{Introduction}

Since the government launched the reform and opening up policy in 1978, China has maintained a comparative advantage and an opendoor policy that focus on the growth of coastal regions to attract foreign investment and stimulate economic growth (Li and Wei 2010). These regions have made remarkable achievements in rapid economic growth and rural development (Xu and Tan 2002; Liu 2007; Wei and Ye 2009). However, with the continuous promotion of the urban- and market-oriented reform, disparities among regions and between rural and urban areas in China have been further widened. The vast central and western regions of China, especially their rural areas, have been lagged behind severely, under the combined effects of the poor economic base and infrastructure, scarcity of human capital 
endowments, market distortions and poor geographical location ( $\mathrm{Li}$ and Qiao 2001; Ying 2003; Li and Wei 2010).

In the last decade, due to the increasing regional and urban-rural disparities, the Chinese central government has paid more attention to solving economic polarization and endorsing programs to alleviate inequality ( $\mathrm{Li}$ and Wei 2010; Chen and Zheng 2008). Major policies adopted by the central government during this period were listed as follows: (1) the Western Development Program (WDP), this program was launched in 1999, in an effort to boost the less developed western 12 provincial-level units (hereafter provinces); (2) the Grain for Green Project (GGP), this project was adopted in 1999 to improve ecological conditions by converting cultivated land with a slope over $25^{\circ}$ to forest or grassland in western provinces; (3) agricultural support policies (ASPs), especially direct grain subsidy policy and agricultural tax breaks policy, which were implemented in 2004 and 2006, respectively, in order to revive farmers' enthusiasm in agricultural production, especially grain production, and to increase their income directly; and (4) building a new countryside strategy (BNCS), it was mapped out in 2005 and aimed to overall coordinate urban and rural development and gear up national economic growth. These above-mentioned socioeconomic development policies can be viewed as central government's responses to coordinate regional and urban-rural development. Therefore, the western China became the policy focus area, and it is necessary to examine the actual effects of these policies after years of implementation.

Numerous studies have been carried out on analyzing the effects of these policies in western China. About WDP, much progress has been made in the construction of infrastructure and ecological environment, and western China's economic development has sped up since the initiation of WDP. However, both urban-rural income inequity in the 12 provinces and the gap between eastern and western China have not been narrowed (Wang and Wei 2004; Lin and Ren 2009; Tian and Huang 2010). About GGP, a small-scale field study at the project level of implementation in Sichuan casts doubt upon the accuracy and reliability of reported success (Trac et al. 2007). Farmers appreciated the grain and financial compensation offered by the
GGP, but few considered planting trees or forage species of being a priority, and a large proportion (37.2\%) planned to return to cultivating forested areas and grassland once the project's subsidies end (Cao et al. 2009). Therefore, the project neglects great differences among geographical areas in the country and much of the restored vegetation has the risks of being converted into farmland and rangeland again (Uchida et al. 2005; $\mathrm{Xu}$ et al. 2007; Cao et al. 2009; Grosjean and Kontoleon 2009). On ASPs, model-based estimation by Kwieciński and van Tongeren (2007) showed that the impact of these policies on gross farm revenues was still relatively small, and Yu and Jensen (2010) suggested that recent policy changes likely have positively addressed the two policy objectives in increasing grain production and farm income. Gui (2008) and Kennedy (2007) found that the abolition of agricultural tax showed positive effects in reducing the burden on peasants in western China, but brought about a sharp drop in fiscal revenue of counties and townships, and thus they suffered more difficulties in providing rural public services. In terms of BNCS, Jiang (2007) surveyed 387 village cadres from 45 counties of Sichuan Province and found that most of them were incapable of leading villagers to play a great role in new countryside construction. These works increased our knowledge of effects of the four policies on rural development.

However, most of these evaluations were either based on regional (provincial) statistic data or household survey data from various villages, few studies probed deeply into the implementation processes, local responses and effects of these policies on typical local communities. Therefore, we still have difficulties in understanding the effects of these policies. Case studies with in-depth inquiry can offer the opportunity to unite quantitative and qualitative information and provide more information for policy evaluation (Midmore et al. 2010). This paper, taking Shuanghe Village, a typical mountainous village in southern Sichuan Province as an example, attempts to analyze the local responses of recent preferential policies by exploring the implementation processes of these policies and their effects on rural system, especially local resources and the environment and thus to gain some policy implications for sustainable rural 
development in western mountainous regions from local perspectives.

\section{Theoretical Context}

The aim of this paper is to explore local responses to recent national policies through case study, and thus to stimulate multidisciplinary debate on the transformation of china's agricultural and rural policies. To some extent, this study is similar to policy evaluation. Policy evaluations can usually contribute to improve decision-making, resource allocation and accountability. Evaluation can take place at any time in the policy life circle, and often a distinction between ex-ante, mid-term and ex-post evaluations is made (Treluin and Roza 2010). Many approaches, methods and tools can be used to conduct evaluations. Treluin and Roza (2010) broadly classify the commonly used 22 evaluation methods in EU policy evaluation into five groups: the Common Monitoring and Evaluation Framework (CMEF) approach, the tally approach, the econometric approach, the modelling approach and the mixed case-study approach. Methods in the first four groups in particular identify quantitative effects of the policy intervention, while the mixed case-study approach tends to focus on the qualitative effects and features in the context of the policy intervention.

In the majority of developed or fast growing countries, agriculture is still important economic sector. But it is now producing fewer and fewer rural jobs. Rural areas suffer from the outmigration of both young and highly skilled workers, leaving an aging population and strained public services. Most rural areas have difficulty mustering the critical mass of capital and infrastructure to encourage and sustain new rural entrepreneurs (Pezzini 2001). Agricultural and rural policies are still integral parts of national policy system. Therefore, more and more evaluators from various countries conclude that traditional sectoral approaches to rural areas have not given the expected results (OECD 2005; Bridger and Theodore 2008; Olfert and Partridge 2010). Moreover, the wide spatial variation in local attribute can also thwart "one size fits all" personbased policies (Partridge and Richman 2006). There is a need for more effective, place-based policies which can better capture the diverse challenges and potential of rural areas (OECD 2003; Bridger and Theodore 2008; Ryser and Halseth 2010).

In particular, the remote rural areas are facing strong structural constraint such as remoteness and backwardness. This constraint should be explicitly recognized in structural policy design and implementation, through integrated and multidimensional policies (Psaltopoulos et al. 2004). An effective place-based policy will identify relationships between a wide range of issues and interests, and develop plans that build on these connections to create balanced and healthy communities (Bridger and Theodore 2008). Moreover, place-based policies have the simple advantage that governments may find it easier to target appropriate poor places than to identify the appropriate poor households with specific attributes (Ravallion and Wodon 1999). Alternatively, if the uneven geographical location of employment opportunities and an unfavorable industry composition are the important casual factors, then place-based policies aimed at improving employment opportunities in distressed areas would be more effective (Partridge and Richman 2006).

As one of the most populous and vast country in the world, China has transformed rapidly ever since the late 1970s. However, the existing huge regional differences in geographical background, bio-geo-physical conditions, and socio-economic development base and other factors made the transformation show significant regional differences, and the agriculture and rural development state shows significant regional differences too (Li and Wei 2010; Long et al. 2011). All these discrepancies presented a great challenge for the formulation and implementation of agricultural and rural development policies, which needs understanding the specific development constraints and options of various regions (Courtney et al. 2006; Ryser and Halseth 2010; Long et al. 2010).

\section{Methodology}

China has promulgated mainly four policies to eliminate east-west inequality and urban-rural 
disparities since the late 1990 . In order to give a holistic evaluation, we try to analyze the four policies in one typical village. This is a little different from most policy evaluation studies which concentrate on one single policy in one or more places. Traditional techniques for evaluating deadweight, substitution and displacement effects only measure the extent to which policy measures fulfill intended policy objectives, but fail to trace the chain of causality from actions to impacts and grapple with more important questions for policy development, such as how and why they operate in the way they do (Baslé 2006; Midmore et al. 2008; Terluin and Roza 2010). Deeper insights can be achieved through investigations of a small but intensively investigated number of cases (Yin 1994), and hence in-depth interpretive investigation was employed to conduct our evaluation (Midmore et al. 2008; Terluin and Roza 2010). In general, the first stage is to analyze the baseline situation in the case study region by means of secondary data. However, it was difficult to describe the baseline situation with socio-economic and environment indicators in the case study village, as data and literature were not readily available. Alternatively, before the evaluation, we will firstly depict the stages of socioeconomic development of study area so as to fully understand the local attributes. Then through indepth interviews with representatives of different interest groups, the process of introduction and implementation of each policy by various actors at provincial level, county level, township level and village level will be analyzed respectively. Further, we will explore their effects on local economy, society, resources and the environment based on field investigations. And an overall evaluation of these four main policies and policy implications will be made finally.

Shuanghe Village $\left(29^{\circ} 16^{\prime} 05^{\prime \prime} \mathrm{N}, 105^{\circ} 18^{\prime} 22^{\prime \prime} \mathrm{E}\right)$, a mountainous village located in the Longchang County, southeast Sichuan Province (Figure 1), was chosen for our case study just because it is common and has similar physical and socio-economic conditions with most of the rural area in southern Sichuan. Longchang County is a major transport node of Chengdu-Chongqing Urban Agglomeration. In 2008, the proportion of the primary, secondary and tertiary sectors accounted for $18.40 \%, 55.85 \%$, and $25.75 \%$ in its total gross domestic product (GDP), respectively. The GDP per capita in Longchang amounted to 12,258 RMBY (US\$ to RMBY: 1-6.95), which was only $54 \%$ of the national average. Shuanghe is $13 \mathrm{~km}$ away from the county seat and $3 \mathrm{~km}$ from the National Highway 321 (G321). Thus its external transportation is convenient. In Chinese, Shuanghe means "two rivers", and this village is actually at the intersection of the Longchang River and the Yujian River. Its altitude ranges between $300 \mathrm{~m}$ and $600 \mathrm{~m}$. The average annual temperature is $17 \cdot 3^{\circ} \mathrm{C}$, and the average annual precipitation is $1,080 \mathrm{~mm}$. Ninety percent of its paddy fields have effective irrigation.
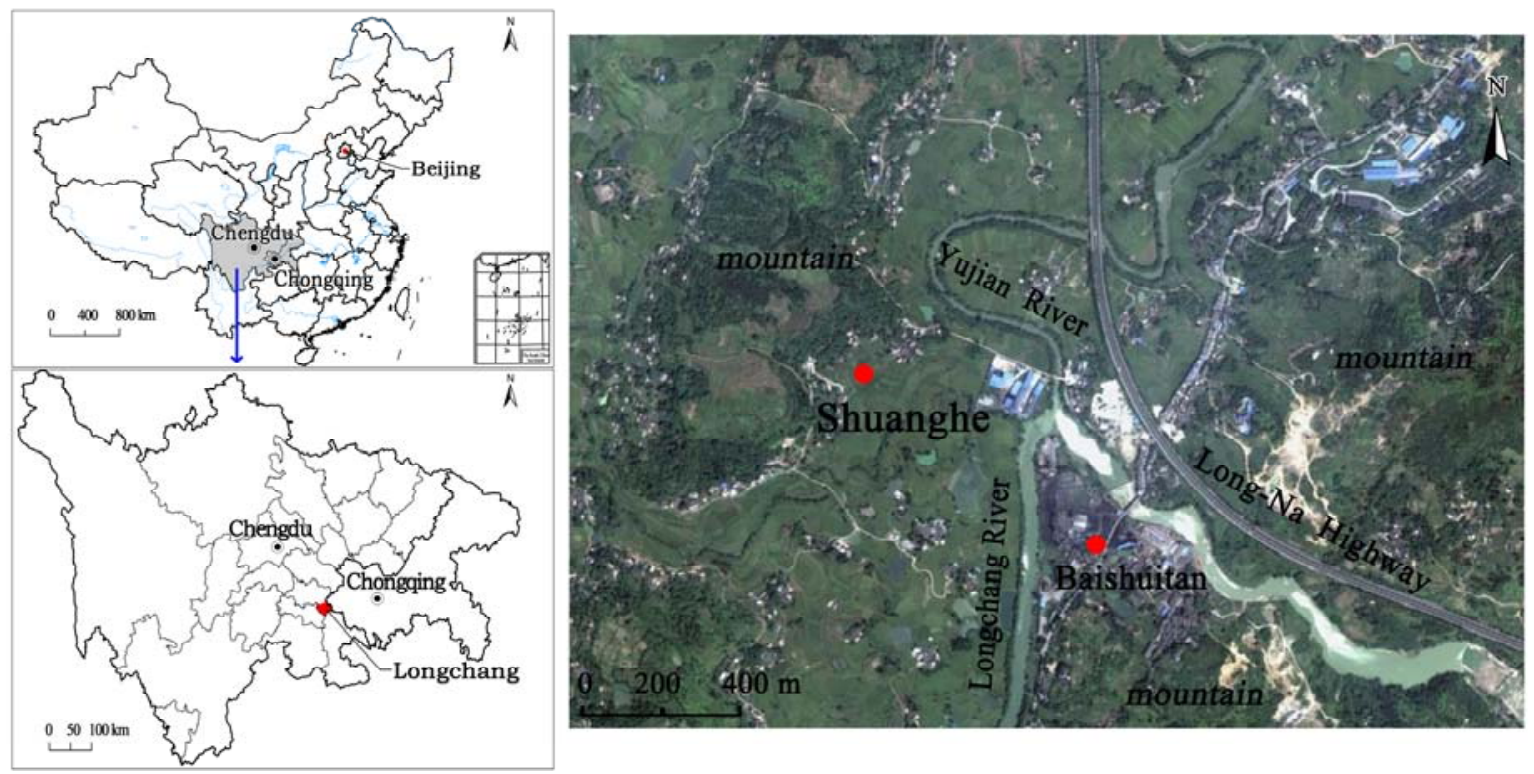

Figure 1 Location of the Shuanghe Village in Sichuan Province, southwest China (Source: the remote sensing image of Shuanghe Village was extracted from Google Earth on April 17, 2012) 
Per capita area of paddy fields was about $0.4 \mathrm{mu}$ $(1 \mathrm{mu}=1 / 15$ hectare), which could produce 220$260 \mathrm{~kg}$ of rice annually. Farmers used to grow paddy rice in the lower areas near the river and plant wheat, corn and potatoes on the slopes for household subsistence. Shuanghe had rich reserves of limestone, and has a long history of limestone mining and processing. Shuanghe had a total population of 312 ( 85 households) in 2008, and per capita annual net income was 3,630 RMB¥, which was about $82 \%$ and $76 \%$ of the county and national average, respectively.

In order to probe deeply into local specific implementation of recent macro socio-economic development policies and their effects on rural system, five times of field investigations in Shuanghe Village have been carried out since February 2008. In February 2008, we conducted semi-structured group interviews with villagers and village head to obtain general information mainly on the implementation of WDP and GGP in this village. In January 2009, we investigated 75 households (with population of 268) and obtained general household information especially on age, educational level, employment and income. Local government officers, teachers in the nearest primary school and middle school were interviewed too. In February 2010, we carried out semistructured group interviews with villagers and village head mainly on Shuanghe's socio-economic developing stages and agricultural production transformation, and in particular the implementation of the strategy of building new countryside and agricultural support policies. Moreover, in October 2010 and January 2012, we carried out the fourth and fifth field investigations to communicate with village head and villagers on implementation processes and resourceenvironment effects of these four macro socioeconomic development policies.

\section{The Stages of Socio-economic Development in Shuanghe Village}

\subsection{9-1982: Mining and traditional agriculture-led village development}

Traditional agriculture and limestone mining and processing were Shuanghe's main economic activities, during this period of time. Shuanghe Village had rich reserves of limestone, and has a history of over 300 years on limestone mining and processing. In rural areas of western China, lime was widely used for rural housing construction, storage of agricultural products and disinfecting fish ponds and so on, thus limestone mining and processing industry was profitable. During the period of 1958 to 1980, limestone industry in Shuanghe was collectively owned commune and brigade enterprises, the predecessors of township and village enterprises. In terms of allocation mechanism, work-point system was implemented until 1980, and then the piecework system was introduced in. Due to limited technological level, production processes like drilling, transportation and kilns at that time was labor intensive. In the late 1970s, more than 50 labors in Shuanghe Village were involved in this industry and villagers shared considerable economic income created by this industry.

As the subsistence sector, agriculture had been paid great attention in this period. Like most of the villages in China, Shuanghe has experienced three kinds of agricultural production and management institution: from 1950 to 1954 , in the form of agricultural production mutual-aid group, which could be characterized by "individual ownership of the land and independent management by every household"; from 1955 to 1982, in the form of agricultural production cooperatives, which could be characterized by "collective ownership of the land and collective management"; after 1983, in the form of household contract responsibility system, which could be characterized by "collective ownership of the land and contract management by every household".

Although most young labor forces worked in the mines, non-agricultural employment has no negative effect on agricultural production. The reason was when busy farming season came, mines would stop production temporarily and workers could participate in agricultural production timely. Cropping pattern was two crops a year in 1950 os and transformed to three crops a year in 1960s. Marginal land was used efficiently. Villagers grew variety of agricultural products, such as rice, sorghum, wheat, corn, sweet potato, rapeseed, peanuts and sugar cane and so on. Grain yield increased slowly during this stage. Rice yield was 
$220 \mathrm{~kg}$ per mu in the early years of $1950 \mathrm{~s}$ and increased to $330 \mathrm{~kg}$ in 1980 . Agricultural products could meet the needs of the family rations and backyard poultry. As one of the main draft animals, water buffalo played an important role both in dry land farming and plowing of paddy fields.

Prior to 1978, rural labor forces were not allowed to work in off-farm activities or out of collective farms, and even in the early 1980s, various institutional barriers deterring labor mobility had not been significantly removed (Cai 2011). Therefore, very few villagers in Shuanghe went outside the village to seek off-farm work at that time. Nevertheless, Shuanghe's agriculture and limestone mining and processing industry developed steadily and provided good solution for the problems of insufficient food and clothing. Most of the old villagers believed that living standard in Shuanghe reached the middle level and was better than remote villages without mineral resources. The wealth gap in village was small.

\subsection{3-1999: Mining, traditional agriculture and labor-sending economy-led village development}

During 1983-1999, institution reform, technical innovation and increased market demand led to a rapid expansion of limestone mining and processing industry. In 1983, most of commune and brigade enterprises in Longchang county experienced property right reform, specifically, it was contracted to individual who was from local village and had the will and ability to manage the enterprise. In Shuanghe, a contract was signed by contractor and commune and brigade. According to this contract, the new enterprise should pay 10 thousand RMBY to the brigade each year for village public expenditure and year-end bonus. For the amount is limited, villagers could receive little money from the annual bonus. However, the village enterprise invested 30 thousand RMBY in construction of a $1.5 \mathrm{~km}$ long tractor road from mine in the mountain to the county road, and thus freight cars could be used in transportation and villagers could share this road too. Limestone production increased from 50 tons per day in the late 1970 s to more than 200 tons per day in the late 1990s. Obviously, the contribution of this booming industry to Shuanghe more reflected in the provision of non-agricultural jobs and investment on transportation infrastructure. Total number of employees increased from about 50 in the late 1970 s to more than 70 in the late 1990s. The average monthly wage of underground workers and female stevedores was high up to about 1,500 RMBY and 600 RMB¥, respectively.

With the deepening of reform and opening up, government's restrictions on rural migration to cities and working in nonagricultural sectors were relaxed (Cai 2011). In Shuanghe, because mine jobs are labor-intensive operation with poor safety instruments, and likely to cause serious occupational diseases such as rheumatism and silicosis, and combined with low economic return of agricultural activity, the non-farm employment in towns and cities became the first choice of young people. Since the middle of 1980 s, urban and town construction accelerated, thus a large amount of plasterers were needed. 10 young villagers learned building construction skills from elders began to seek work in county town in 1986. And in 1988, they succeed in finding new jobs in Guangzhou City and Shenzhen City, the main battlefield of China's reform and opening up. Influenced and introduced by them, to the late 1990 s, more than 50 villagers, mainly young men, worked in non-agricultural sectors outside the county, and about 30 of them were in the construction industry. As a result, diversity of employment increased significantly.

In terms of agriculture, because of the implementation of household contract responsibility system, the wide extension of hybrid rice and widely use of chemical fertilizer and pesticides and other modern agricultural factors, rice yield showed a significant increase, from 330 $\mathrm{kg}$ per mu in 1980 to $430 \mathrm{~kg}$ per mu in 1985 . But gradually, as the state regained control of agricultural products prices in 1985 (Yang and Li 2008), agricultural production, especially grain production fell into a dilemma that higher output was not accompanied by a higher income. Compared with non-agricultural economic activities, traditional agriculture became more and more economic inefficient, thus lack of comparative effectiveness. The opinion of "planting enough for grain ration is ok" was widely accepted. Households with migrant labor gradually reduced their labor input in agricultural production. The evolution of crop pattern was a proof of decrease of 
cultivated land use intensification. Crop pattern of paddy field change from "rice-wheat or rapeseed" even "rice-rice-wheat or rapeseed" to single cropping of rice, while crop pattern of dryland changed from "wheat-corn or sorghum-sweet potato" to "wheat-sweet potato". In the late 1990s, marginal land, which had been efficiently used before 1985, was abandoned gradually.

During this stage, local community of Shuanghe gave immediate responses to commune and brigade enterprise restructuring, agricultural production and management system innovation and technical progress and thus produced positive effects. With the diversification of economic activities, villagers' living standard increased considerably, and $70 \%$ of the resident households built brick houses. However, the income gap also increased rapidly. In 1999, the ratio of average net income of farming households to farming and mining households to off farming households was about 1:2.4:3. Agricultural production experienced rapid growth at the beginning of this period, but for lack of economic efficiency compared to off-farm work, declined steadily since then.

\subsection{Since 2000: hybrid village development}

The implementation of macro socio-economic development policies affected the village development profoundly. Limestone mining and processing industry experienced a rapid prosperity during the early stage of WDP because of the increasing market demand, but then sudden perished for the depletion of limestone. There is no doubt that the decline of limestone mining and processing industry has had a drastic effect on the employment situation and general prosperity of Shuanghe Village. However, the diversified economy partly mitigated the effect. On the one hand, two new enterprises settled down, and brought about new jobs. One the other hand, the WDP has brought about large number of employment opportunities especially in cities, thus more and more rural labors swarm into cities. In terms of agriculture, due to the rapid decrease of cultivated land and limited economic return, agricultural production in Shuanghe experienced a further decline. In short, driven by the development policies and the quick decline and demise of limestone mining and processing industry, Shuanghe has entered a new period of development since 2000, which could be briefly summarized as increasing migrant labors, diversified employment, but a stagnant agriculture and village development. Further analyses on village development during this stage will be given in the next part.

\section{Policies, Local Responses, and Their Effects on Rural System}

\subsection{The Western Development Program}

In 1999, China promulgated the WDP, which in some ways represents the first real step towards developing the country's immense interior. This strategy has also helped to subdue the significant social and economic discontent resulting from the regional disparities (Chen and Zheng 2008). The main components of the WDP include the development of infrastructure, enticement of foreign investment, increased efforts on ecological protection, promotion of education, and retention of talent flowing to richer provinces (Goodman 2004; Yeung and Shen 2004). During 2000-2009, the amount of national investment in western key projects reached 2.2 trillion RMBY, and the central government transfer payments to the west totaled more than 3 trillion RMBY. After years of implementation, substantial progress has been made in the construction of infrastructure projects and work has started in all aspects of the construction of ecological environment (Wang and Wei 2004; Yao and Ren 2009). In terms of Sichuan, aimed to be the economic powerhouse of China's west and a bulwark for environmental protection along the upper reaches of the Yangtze River, detailed policy implementation contains interesting responses and variations to central dictates, and significant effects have resulted from the campaign's initiation (McNally 2004).

In Longchang, the county government, town government, local villagers and investors from inside and outside the county gave immediate responses to the WDP. Both county government and township government took the opportunity to acquisitioning land to enlarge industrial park, thus hoped to attract domestic and foreign investment. 
The county government has planned and constructed two industrial parks in county town with a total planning area of 1,200 hectares. In the context of WDP, county government has issued a series of preferential policies on tax relief, land access, fees and charges relief and financial incentives to create a relative better environment than surrounding counties for scrambling for investment. Meanwhile, the government of Yunding Town also promulgated similar preferential policies and built an industrial concentration area in the township and an industrial park in Baishuitan, where there was a former state-owned coal mining enterprise but perished because of mine exhaustion. Shuanghe was included in Baishuitan industrial park mainly for its comparative advantage in resources endowment and location. One township officer explained the situation about the sudden emerge of various industrial parks:

Every town is now in the race to build industrial park so as to attract industrial investment and then realize rapid economic growth. Attracting investment and land acquisition became the main mission of township government officers. The quota was assigned by higher-level government, and if you haven't achieved the assigned goal, you will have trouble in year-end evaluation and future promotion.

Shuanghe was involved in the WDP directly. This could be summed up in three aspects. Firstly, it is local mine exploitation. Infrastructure construction, which is of primary importance in the WDP, has been vigorously promoted, and hence caused a large demand for limestone, which is now widely used as lime, cement, glass raw material, refractory, and ingredient in chemical processes. Driven by the huge demand and considerable income, both the mine contractor and miners has been working at full capacity since then. As a result, the daily output of limestone in 2003 went up to 260-300 tons. However, the limestone reserves in Shuanghe fell rapidly. Having been exploited for centuries, the industry finally perished in 2008.

Secondly, extraneous enterprises settled down. Attracted by the preferential policies and increasing inland market, more and more investors, especially from Zhejiang and Jiangsu Provinces, came to seek new development opportunity. Shuanghe was attractive to investors because of its water resource endowments and geographical location. More than ten investors expressed their willingness to build plants on a piece of paddy fields near the intersection of the two rivers. At last, two enterprises were settled down, one was a glass wool factory, the other was a paper mill with annual output of 20 thousand tonnes of paper. During the past several years, the two factories have brought considerable taxes to the local government, and thus township officers may have submitted in a passable transcript. However, they have also brought about huge pressures on land resources and the local environment and thus threatened the sustainable development of Shuanghe Village. Besides the occupation of $35 \mathrm{mu}$ high qualified paddy fields (Figure 2), the two enterprises also brought about serious pollution emissions, from which the river and air suffered

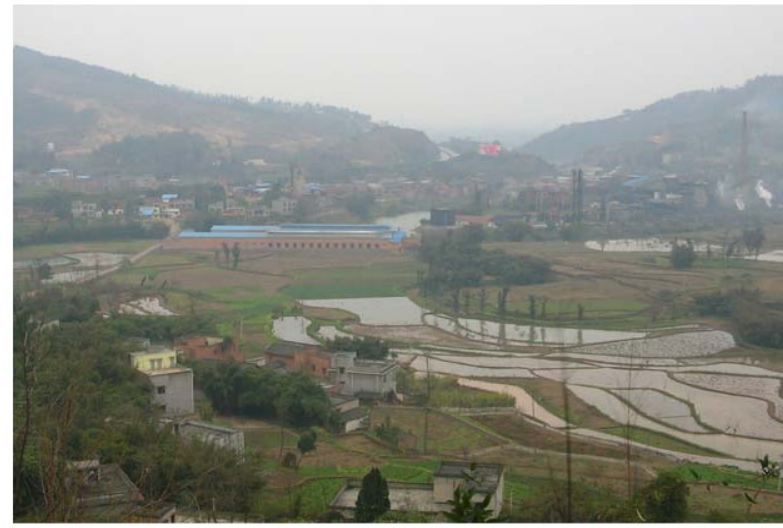

(a) February 9, 2008

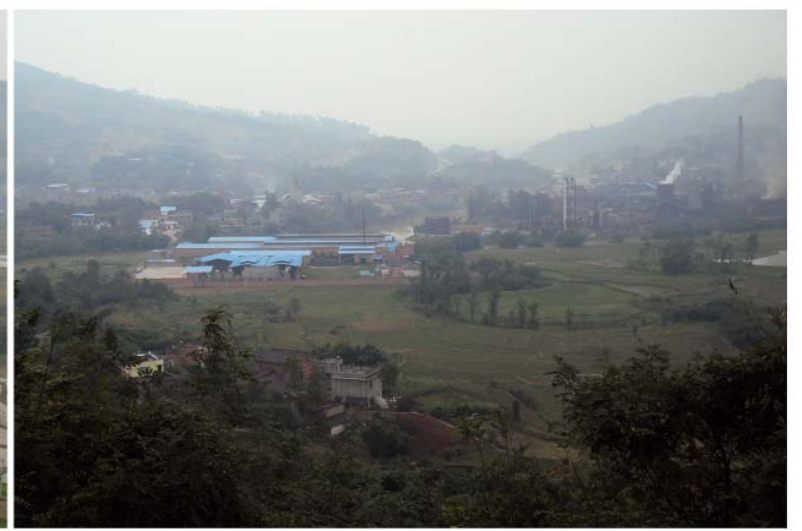

(b) October 7, 2010

Figure 2 Land-use change in Shuanghe Village driven by industrial development Note: Buildings with blue roof are enterprises' plants; about $35 \mathrm{mu}$ high qualified paddy fields were occupied by the two enterprises (photos taken by the first author). 
much. As the village head and villagers complained:

At the beginning, villagers and I all had illusions about these enterprises. They may bring about considerable job opportunities to us and we would not have to seek jobs in cities far away from home, and thus our village may be revitalized. However, all of us very much regretted finally. Land acquisition is inevitable, but the standard of compensation was too low and the way of compensation was also questionable. The local government bought our land at the cost of only 35 thousand RMBY per mu. Land served us with basic food, but now we lost it forever. With this amount of money, we could do few things, because the commodity price is rising heavily. We need unemployment insurance and social security rather than cash.

Besides paddy fields occupation, the operation of the two factories has brought about serious environmental pollution to our once beautiful village. The white glass fibers pellets were blown miles away by the wind, while the sewage discharged from the paper mill blackened near half side of the Longchang River. But now we have no way to stop them, because they have passed the environmental impact assessment, and have their way to get the government's support so that they could take action before the local Environmental Protection Agency's working group come to inspect and sampling. Fortunately, due to the economic crisis and the increase of cost, the two enterprises often suspend production, and thus the pollutions reduced.

Thirdly, that is cityward migration for off-farm work. Labor force is one of the most important resources for regional/rural development. With the increase of employment opportunities driven by WDP , villagers in Shuanghe left the familiar village they had lived for years so as to seek jobs in cities and towns, where could supply non-agricultural jobs with higher wages. In 2008, there were 117 villagers earned their living in areas outside the town (Table 1), the amount of "out migrants" minus "students" and "others"), which accounted

Table 1 Socio-demographic characteristics of Shuanghe Village in 2008 (Source: authors' survey)

\begin{tabular}{|c|c|c|c|c|c|c|c|c|c|}
\hline & & \multirow[b]{2}{*}{ Population } & \multirow[b]{2}{*}{$\begin{array}{l}\% \text { of sub } \\
\text { category }\end{array}$} & \multicolumn{5}{|c|}{ Education level } & \multirow[b]{2}{*}{$\begin{array}{l}\text { Average } \\
\text { age }\end{array}$} \\
\hline & & & & Illiterate & $\begin{array}{l}\text { Primary } \\
\text { school }\end{array}$ & $\begin{array}{l}\text { Junior } \\
\text { high } \\
\text { school }\end{array}$ & $\begin{array}{l}\text { Senior } \\
\text { high } \\
\text { school }^{1}\end{array}$ & $\begin{array}{l}\text { College } \\
\text { and } \\
\text { above }\end{array}$ & \\
\hline \multirow{8}{*}{$\begin{array}{l}\text { Left- } \\
\text { behind } \\
\text { villagers }\end{array}$} & Children $^{(2)}$ & 18 & 13.95 & 100.00 & 0.00 & 0.00 & 0.00 & 0.00 & 3.17 \\
\hline & Students & 26 & 20.16 & 0.00 & 61.54 & 38.46 & 0.00 & 0.00 & 11.88 \\
\hline & Farmers $^{(3)}$ & 35 & 27.13 & 40.00 & 42.86 & 14.29 & 2.86 & 0.00 & $55 \cdot 59$ \\
\hline & OW & 9 & 6.98 & 0.00 & 100.00 & 0.00 & 0.00 & 0.00 & 36.11 \\
\hline & $\begin{array}{l}\text { Individual } \\
\text { enterprises }\end{array}$ & 16 & 12.40 & 12.50 & $37 \cdot 50$ & 18.75 & 31.25 & 0.00 & 42.81 \\
\hline & $\begin{array}{l}\text { Unemployed } \\
\text { labors }\end{array}$ & 8 & 6.20 & 0.00 & $37 \cdot 50$ & 50.00 & 12.50 & 0.00 & 38.88 \\
\hline & AP & 17 & 13.18 & 52.94 & 41.18 & 5.88 & 0.00 & 0.00 & 70.06 \\
\hline & Subtotal & 129 & 100.00 & $33 \cdot 33$ & 43.41 & 17.83 & 5.43 & 0.00 & 37.13 \\
\hline \multirow{7}{*}{$\begin{array}{l}\text { Out } \\
\text { migrants }\end{array}$} & $\begin{array}{l}\text { Construction } \\
\text { workers }\end{array}$ & 22 & 15.83 & 0.00 & 72.73 & 22.73 & 4.55 & 0.00 & 38.64 \\
\hline & $\begin{array}{l}\text { Limestone } \\
\text { miners }\end{array}$ & 31 & 22.30 & 0.00 & 61.29 & 3.23 & 29.03 & 6.45 & 41.87 \\
\hline & $\begin{array}{l}\text { Factory } \\
\text { workers }\end{array}$ & 32 & 23.02 & 3.13 & 34.38 & 40.63 & 21.88 & 0.00 & 33.91 \\
\hline & $\begin{array}{l}\text { Other } \\
\text { industries }\end{array}$ & 32 & 23.02 & 3.13 & 31.25 & 50.00 & 15.63 & 0.00 & 37.28 \\
\hline & Students & 18 & 12.95 & 0.00 & 27.78 & 22.22 & 22.22 & 27.78 & 15.28 \\
\hline & Others ${ }^{(4)}$ & 4 & 2.88 & 25.00 & 25.00 & 50.00 & 0.00 & 0.00 & 46.25 \\
\hline & Subtotal & 139 & 100.00 & 2.16 & 44.60 & 29.50 & 18.71 & 5.04 & 35.15 \\
\hline Total & & 268 & 100.00 & 17.16 & 44.03 & 23.88 & 12.31 & 2.61 & 36.10 \\
\hline
\end{tabular}

Notes: (1) including technical school; (2) children under the age of 6; (3) including people above the age of 6o but still involved in agricultural production; and (4) refers to unemployed out-migration labors and aged people. OW = Off-farm workers in enterprises of Shuanghe; AP = Aged people without farm work. 
for $59.69 \%$ of Shuanghe's total labor force. Our household investigation showed that these migrant labors could be divided into three categories (Table 1): the first category was experienced construction workers who engaged in this industry for years and now most of them worked in Chengdu and Guiyang, the capital city of Sichuan Province and Guizhou Province, respectively. There were 22 people in this category, with per capita annual net income about 20-30 thousand RMBY. The second category used to work in limestone mining and processing industry in the village, but now followed their former boss and moved to another limestone mine in Zizhong County, $70 \mathrm{~km}$ away from Longchang County. There were 31 people in this category, with per capita annual net income about 35-45 thousand RMB¥. The third category was relative young people, most of which had not been admitted to universities or even high school. On the recommendation of relatives or friends, most of them succeeded in obtaining employment as industrial workers in manufacturing factories or engaged in individual business in Pearl River Delta and Chengdu, where now still thirst for cheap labor, thus they became the new generation of migrant workers. There were 64 people in this category, with per capita annual net income about 15-25 thousand RMBY.

As we have seen, the implementation of the WDP has both positive and negative effects on local village system. On the one side, the WDP has accelerated the pace of infrastructure construction and resources exploitation, and provided considerable off-farm jobs for villagers and thus brought about new opportunities for village development in the early 21st century. On the other side, the WDP has accelerated the pace of resource exhaustion and caused environmental pollution and the loss of high quality farmland. In particular, development zone fever, which was popular in eastern coastal China under rapid industrialization (Yang and Wang 2008), has been spread to rural areas of less developed western China. The pollution industry transfer particularly from developed regions also became great threat for the sustainable development of less developed western regions with lenient environmental liability regulation.

\subsection{The Grain for Green Project}

The Grain for Green Project is a significant ecological restoration project in China that was launched in 1999 and covers approximately 13 provinces (or municipalities) ${ }^{\circledR}$. Its objective is to improve ecological conditions by converting cultivated land with a slope above $25^{\circ}$ to forest or grassland in the upper Yangtze River Basin and the middle and upper Yellow River Basin. Food supplies and cash are awarded to farmers for their loss of income due to land conversion ( $\mathrm{Xu}$ et al. 2007; Liu et al. 2008; Cao et al. 2009). In 2004, payments in kind were converted to cash equivalents. The period for which "retired" land is subsidized is set at two years for land returned to pasture, five years for land converted to "economic" forests and eight years for land converted to "ecological" forests (Kwieciński and van Tongeren 2007).

From 1999 to 2009, a total of 27.7 million hectares of cultivated land has been converted into forest, and farmers in 2,279 counties of 25 provinces (or municipalities) received compensation and subsidies from the government. The compensation and subsidies accumulated up to 233 billion RMBY, and an additional 200 billion RMBY is to be earmarked to continue the project in the following ten years. In Sichuan Province, 20 billion RMBY has been invested in ecological construction and a total of 1.8 million hectares of cultivated land has been converted into forest, and thus the percentage of forest cover increased to $31 \%$. In addition, soil erosion has been controlled in a total area of 445 thousand hectares, and sediment flows into the Yangtze River reduced by $46 \%$. In Longchang County, the GGP began in 2000. From 2000 to 2005, a total of 40 thousand $\mathrm{mu}$ of cultivated land was converted into forest, and 42 thousand farmers in 275 villages of 18 towns receiving compensation and subsidies accumulated to 46.70 million RMB¥ from the government. By 2008, 60 thousand $\mathrm{mu}$ of cultivated land had been converted into forest.

In Shuanghe Village, the project received strong support from most villagers and was carried out smoothly at the beginning mainly because villagers' income depend less on sloping land

\footnotetext{
De 13 provincial-level units are Yunnan, Sichuan, Guizhou, Chongqing, Hubei, Shaanxi, Gansu, Qinghai, Ningxia, Inner Mongolia, Shanxi, Henan and Xinjiang, respectively. The number of provinces has been further expanded to 25 since 2002.
} 
cultivation than before. Villagers used to grow wheat and sweet potato on the sloping land for raising pigs. However, due to frequently outbreak of pig diseases and increasing price volatility since 1998, risk-averse households decided to adjust the production structure. Meanwhile the WDP and economic globalization have brought about huge demand for non-agricultural employment, the majority of villagers finally chose to go out for offfarm work or just give up grow crops on sloping land. The GGP carried out in 2000 was just in time. Consequently, a total of $130 \mathrm{mu}$ cultivated land with a slope above $25^{\circ}$ has been converted to forest.

However, this was not the whole story. In 2000, the $130 \mathrm{mu}$ land was all used for the cultivation of Chinese prickly ash. However, villagers' planting techniques were poor, thus led to low survival rate, low output and little economic return. In the spring of 2003, funded and hired by the government, villagers then planted pines and poplars, but also failed in reforestation because of mismanagement and consequent low survival rate and serious occurrence of pest and disease. Then the local government decided to plant black locust in 2005, because of its high growth speed, great adaptation to the environment, and prominent ecological function. Nevertheless, most of the locust trees were cut down in 2007 due to limited economic benefits, and replaced by moso bamboo, which has been highly encouraged in surrounding counties for its relative high economic benefit from selling bamboo shoots. In our field investigation in February and October of 2010, villagers came to complain the decreasing price of fresh bamboo shoots caused by oversupply. Thus far, Shuanghe has experienced four times of planting trees and three times of cutting down, and there are now at least five kinds of trees or bamboo on the hills (Figure 3). With the rapid growth of trees, bushes and grasses, former narrow and winding mountain path was suddenly occupied by sundry trees and it became hard for people to climb up the hill. In case of fire, it is impossible for fire truck and fireman to get to the upper fire spot, and forest may be seriously damaged. From 2000 to 2009, three fire incidents occurred in Shuanghe and more than 100 mu forest were scorched (Figure 3). An interviewee provided his opinion on the implementation of GGP:

We farmers support the GGP and appreciate the grain and financial compensation offered by the central government. I think there are three reasons. Firstly, high cost and low economic return of mountain farming. Cultivation in the sloping land is a hard work and the return shrinks rapidly. Young adults, who can bear the labor intensity, prefer to seek jobs in the cities. Secondly, the grain and financial compensation is moderate and timely, and well compensated our economy loss. Thirdly, ecological environment could be improved quickly. Our village experienced a trap of "plant-cut-plant-cut" like most of the surrounding villages in the past ten years, but now the hills are turning green and the population of birds and beasts are increasing significantly. Moreover, we oppose local government's way of implementation. We believe that the county and township government officers can get rake-off from buying saplings again and again. On the contrary, we farmers can get little economic benefit from reforested land once the project's subsidies end in the near future. This is our collective land, thus we should have right to decide what kind of trees to plant and enhance our ecological condition and economic benefits.

There is no doubt that the implementation of GGP has brought about significant ecological benefits. However, poor progress has been found in the development of forest related industry and consequent increment of job opportunity. Thus, how to guarantee farmers a basic living after government subsidies come to an end is still in question. What was worse, villagers' distrust to the local government increased. In addition, our investigation also found the potential fire risk for lack of systematic and scientific planning. As a result, the village's ecological, economic and social sustainability was still unstable.

\subsection{Agricultural support policies}

Agriculture is one of the most important industries in China. However, rural residents solely relying on farm income have experienced much slower income growth in recent years, which increasingly threatens sustainable agricultural and rural development, especially poverty alleviation and national grain production. China has carried out a series of agricultural support policies since 


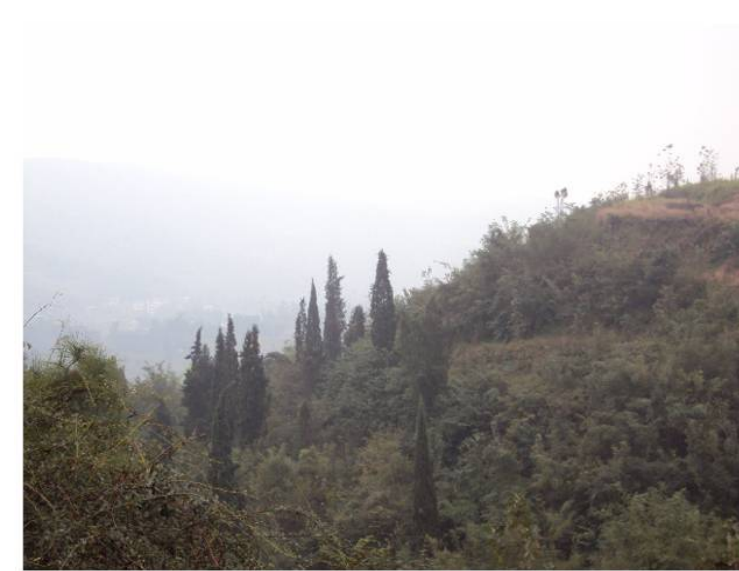

(a) October 7, 2010

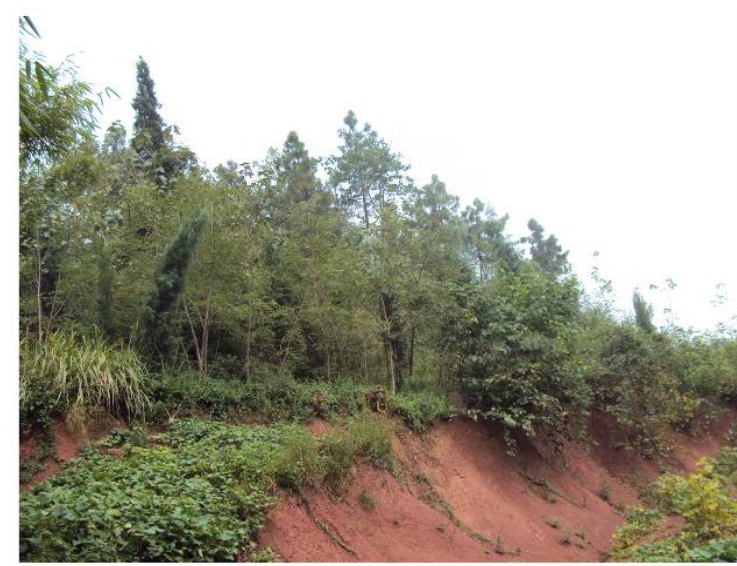

(c) October 8, 2010

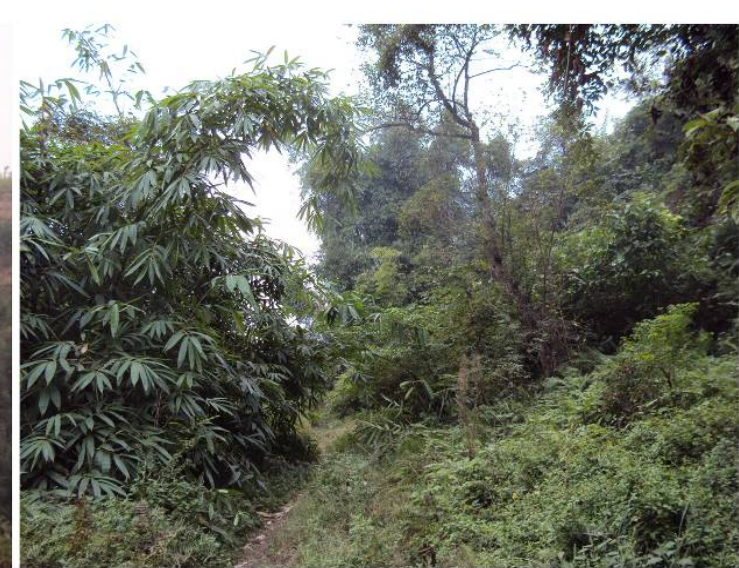

(b) October 8, 2010

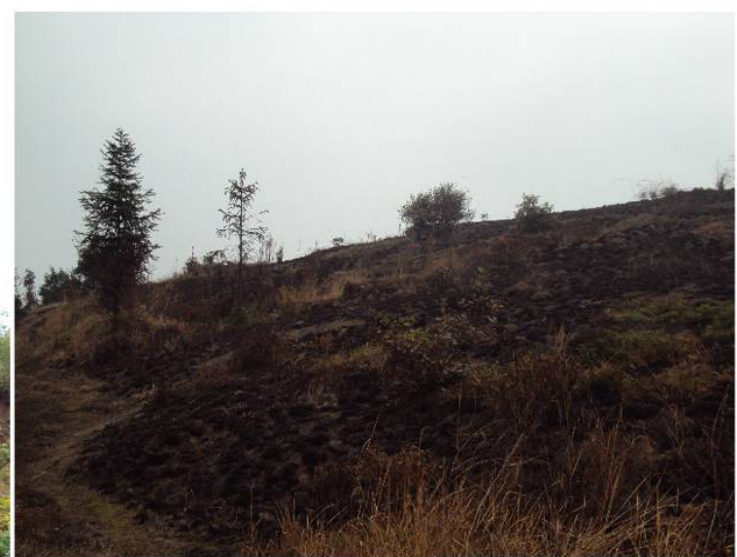

(d) October 7, 2010

Figure 3 A glance of Shuanghe's forest resulted from Grain for Green Project (GGP)

Notes: Shuanghe has experienced a trap of "plant-cut-plant-cut" like most of its surrounding villages. As a results, the forest are hybrid (picture $a, b$ and c); picture b also shows that the former tractor road had been occupied by trees and bamboos; picture c reveals that villagers cultivated on the forested areas again; and from picture d we can see that due to lack of fire lane and poor accessibility, fire had caused serious damage to the young forest (photoed by the first author).

2004, so as to arouse farmers' enthusiasm for pursuing grain production and increase their income (Huang et al. 2011). The central government started to provide various subsidies, including direct payments to grain producers based on planting areas, direct subsidies to purchased farm inputs, subsidies to seeds, and subsidies to agricultural machineries. In 2006, another heartstirring policy was carried out. Agricultural tax, which has existed for about 2600 years, was completely abolished. Detail of the policy evolution could be seen in $\mathrm{Yu}$ and Jensen (2010) and Kwieciński and van Tongeren (2007). It is also worth mentioning that, a set of stringent mechanism were established to farthest eradicate subsidies embezzled by local governments and village committees, so that the farmers can get the total subsides timely and easily. Beyond these, high level policy documents, including the "No.1 Documents", the top priority documents adopted jointly at the beginning of each year by the Central Committee of the Communist Party and the government, clearly outline these policy objectives during 2004-2012. Thus, China's agriculture policies have undergone some fundamental changes in recent years, and went into a new transitional period.

Encouraged by central government, financial support for agricultural and grain production increased significantly. These subsidies amounted to 31.05 billion RMBY and 42.70 billion RMBY in 2006 and 2007, respectively (Yu and Jensen 2010). The amount increased to more than 100 billion RMB¥ in 2008 and a record high 123.08 billion 


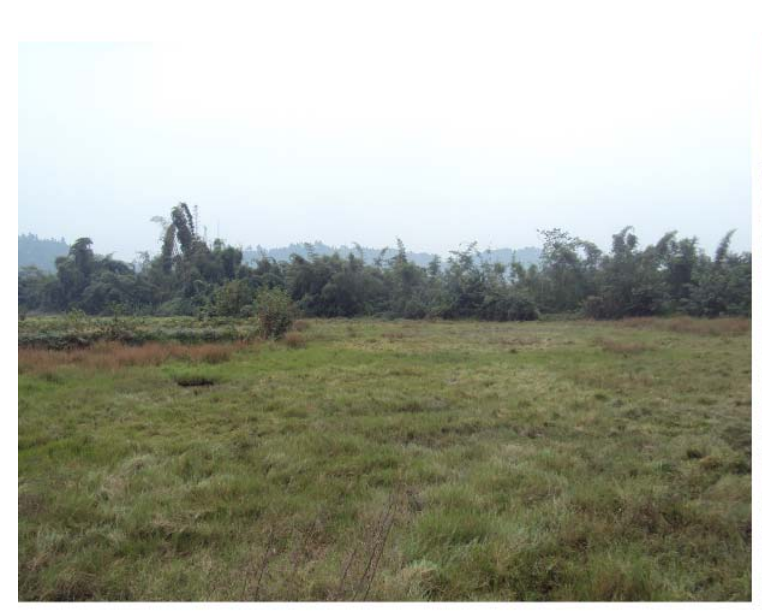

(a) October 7, 2010

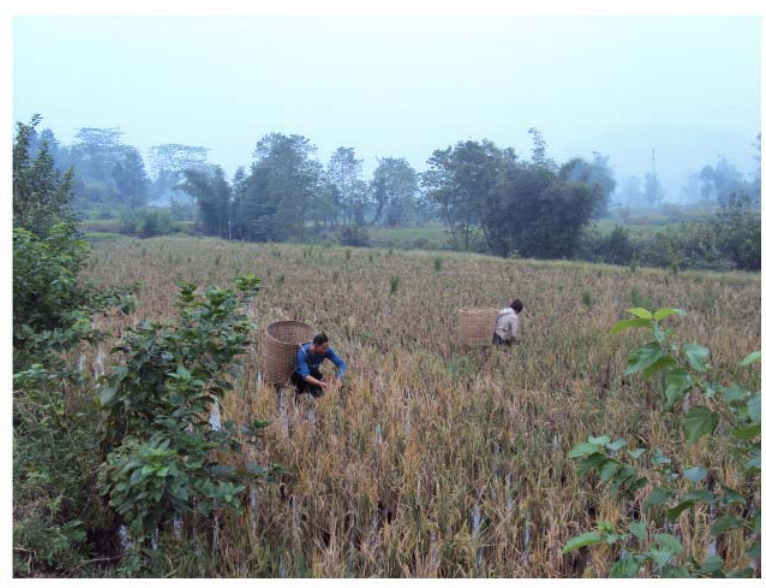

(b) October 8, 2010

Figure 4 Agricultural land use in Shuanghe Village (a) the abandoned high quality paddy fields near the Yujian River; (b) the ratooning rice harvest scene (photos taken by the first author). Obviously, agricultural production in Shuanghe is still being very traditional and run at low-level efficiency.

RMB¥ has been spend on these fields in 2009. The central government paid high attention to the implementation of these policies and the payment of these subsidies was closely monitored by relevant department. Provincial and county-level government implemented these ASPs on schedule.

In Shuanghe, villagers gained their subsidies annually on schedule. However, the effects of ASPs were limited and agricultural production shrank obviously. On the one hand, the decrement of cultivated land led to a sharp decrease of agricultural output. A total of $100 \mathrm{mu}$ cultivated land with a slope above $25^{\circ}$ converted to forest due to the implementation of the GGP, while the newly stationed two enterprises occupied $35 \mathrm{mu}$ high quality paddy fields, that is, the area of cultivated land decreased from $250 \mathrm{mu}$ to $115 \mathrm{mu}$, a $54 \%$ decline. On the other hand, cultivated land use intensity declined significantly due to the limited economic return of traditional agricultural production $^{(2)}$. Just over ninety percent of paddy fields grew single rice only, while the area of winter fallow field rose up to $100 \mathrm{mu}$, and $10 \mathrm{mu}$ of high quality paddy fields near the river were abandoned (Figure 4). As a result, per capita grain production of Shuanghe decreased from $420 \mathrm{~kg}$ in 2000 to 230 $\mathrm{kg}$ in 2008. On these subsidies, the village head stated:

We highly appreciate the direct subsidies and the reductions of agricultural taxes and fees, our total household income increased. However, this contributed little to the increase of net household income, because the overwhelming increase of agricultural means of production significantly caused the rapid increase of cost of agricultural production. For example, the price of fertilizer increased by 20\% just in 2004, the first year of directing payments to us grain producers. Frankly speaking, the policy of direct payments to grain producers based on cultivated land areas cannot motivate farmers to plant grain, because any farmers can get the subsidies if they have farmland, regardless of whether they plant grain or not, even abandon cultivation. In addition, if you leased your land to me, and thus I would be the actual grain farmer, but I have no right to get part of your subsidies. We think this is also debatable.

One interviewee explained why villagers still plant rice but not other crops with higher return:

\footnotetext{
(2) Together with interviewees in Shuanghe Village, we calculated the cost-benefit of rice production in this region in 2009. The results showed that a farmer can only obtain profit of 729 RMBY, which still includes his man-days pay, from planting $1 \mathrm{mu}(1 / 15$ $\mathrm{hm}^{2}$ ) rice: the annual yield is $600 \mathrm{~kg}$, the price is 1.84 RMBY per $\mathrm{kg}$, and the total income from planting rice is 1104 RMBY; however, the total expenditure is 375 RMBY, which includes 30 RMBY for seeds, 60 RMBY for plowing land, 110 RMBY for fertilizer, 15 RMBҰ for pesticide, 6o RMBҰ for irrigation, and 100 RMB¥ for harvest, respectively. If we add total subsides to the profit (about 40 RMB¥ per mu), then final profit would reach 800 RMB¥. However, he can earn 50 RMB¥ per day if he pursues other labor activities on building site or factory. Moreover, by calculating the data abstracted from NDRC (2005, 2009), we found that cost of fertilizer per mu of Sichuan Province increased from 56.56 RMBY in 2004 to 99.49 RMBY in 2008 while the average rate of profit of rice production decreased from $84.72 \%$ to $79.81 \%$.
} 
Though we could get low net income from rice production, we remain willing to plant rice. There are three reasons. Firstly, less labor and skill are needed in rice production than most of other cash crops, thus we could seek off-farm jobs when there is no farm work, or request our parents to do field management. Secondly, both the market risk and natural disaster risk of rice production are relatively small. Thirdly, rice is our staple food, if we bought rice for everyday eating, it would be really a big pressure on cash expenses.

Our demographic household investigation showed that (Table 1), there were only 35 villagers solely relied on farm income, and the average age of them was high up to 56 years old. In rural China, most of them would be grandpas or grandmas. In contrast, the average age of out migrant workers was only about 38 years old. Though the leftbehind on farm workers were experienced in agricultural production, they were so old that they can hardly manage it, especially the labor-intensive rice harvest.

Obviously, ASPs played little role in the increment of grain production and rural income because subsidies per capita were relative low and have been distorted during the course of implementation. In addition, the prices of agricultural means of production rose rapidly and thus encroached on the space of farm income increase. Farmers still could not get their expected profit from grain production. Because of the high risk of cash crops, cityward migration of young and middle-aged rural labor forces and aging of agricultural labor, cropping pattern changed from multiple cropping to single rice obviously, which need less hard physical labors, techniques and time in field management (Figure 4). The implementation of GGP and introduction of enterprises directly caused a sharp decrease of farmland. Under these circumstances, the agriculture in Shuanghe Village shrunk gradually. Shuanghe has been facing increasing difficulties in converting traditional subsistence farming managed by aging labor forces to local-based agrofood economy.

\subsection{The strategy of building new countryside}

Under the pressures of both the recently widening income gap between the rural and urban residents and the problems related to farmers, agriculture and rural areas (so called "san nong wen ti" in Chinese), an epochmaking strategy on "building a new countryside" was put forward in late 2005. Its aim is to boost modern agriculture, develop new relationships between industry and agriculture, cities and countryside, and increases rural affluence. In this policy, a 'new countryside' means advanced production, improved livelihood, clean and tidy villages, a civilized social atmosphere and efficient management. To a great degree, building a new countryside in China is a kind of macroeconomic development strategy aiming at rural restructuring under globalization (Liu 2007; Long et al. 2010; Long and Woods 2011). According to various documents from the website of the Ministry of Finance of China, the Chinese government has spent 297.50 billion RMBY in agriculture, rural areas and farmers in 2005, and the amount increased to about 600 and 716.14 billion RMBY in 2008 and 2009, respectively. These funds have been mainly used for strengthening the development of basic farmland, accelerating construction of infrastructure projects such as roads, drinking water supplies, methane facilities, power grids and communications.

The government of Sichuan Province attached great importance to building new countryside. Under the guidance of central government's concepts and requirements, a series of major construction projects mainly on water conservancy infrastructure construction, farmland consolidation, improving the living conditions of rural communities through drinking water supply and sanitation construction have been carried out. In 2007, the provincial government initiated a new project named "Ten-Hundred-Thousand-Ten thousand Project" (so called "shi-bai-qian-wan gong cheng" in Chinese) to accelerate the pace of building new countryside. This project planned to establish ten ecological demonstration counties, one hundred environmentally beautiful towns, thousand ecological villages and ten thousand ecological homes by 2010. Particularly, the thousand ecological villages should meet five requirements as follows: (1) at least one mainstay project to promote income growth; (2) a group of complete set of infrastructure; (3) a team of new farmers adapted to modern agricultural 
development; (4) a pioneering village leadership; and (5) a beautiful sight of civilized social atmosphere with clean and tidy environment.

Longchang responded actively to policies and plans carried out by national and provincial government. Purun Town was selected as the unique model planned as a whole to pressing ahead with new countryside construction, and a total of 42.87 million RMBY has been invested in improving infrastructure and environment and developing mainstay industry in recent years. In the meantime, Jiefang Village in Hujia Town was selected as one of the sixty key villages of Sichuan Province to build new countryside and 3.64 million RMB¥ was allocated, also because it has very good economic development base. However, the majority of other conventional towns and villages gain little attention from higher authorities.

In Shuanghe Village, when referring to building new countryside, villagers described their dilemmas:

Firstly, advanced production. The limestone mine was shut down, while new enterprises look like a demon, and we farmers cannot expect to earn living by growing rice on shrinking paddy fields.

Secondly, improved livelihood. The only way to earn living is to seek off-farm jobs in cities. We can earn more money through this way, but we have to go back to hometown when we are old, have serious illness or injured, because it is impossible for us to become "local people" of those cities and have equal welfare with urban registered population. For floating people, life is difficult.

Thirdly, clean and tidy villages. The environment in our community is just ok, but because of serious out-migration of villagers, most of the former roads are now covered with thick grass. Water pollution would be a long-standing problem. Fourthly, a civilized social atmosphere. Public security in the village is good. But villagers get sluggish, for more and more left-behind villagers went to gambling in teahouse. Fifthly, efficient management. Because agricultural tax has been abolished and subsidies were paid through household deposit book, public affairs of the village committee decreased, not to mention the effective management. It is worth mentioning that, because more than half of the villagers have migrated out, it became increasingly difficult in convening villagers to participate in villagers assembly.

The village head explained the situation,

The strategy of building new countryside has been mapped out by the central government years ago. However, like most of surrounding villages, the trajectory of development in Shuanghe changed little. We got no direct support from local government. You know, without government's support, it is hard for us to make it. The local government did not want to pay attention to us just because we were poor when they implemented this strategy. They prefer to invest in relative affluent villages, thus these villages can became a good model immediately. This is let the better villages to develop better more. In other words, local government prefers icing on the cake, but I think, to some extent, it is waste of money.

An interviewee provided his opinion on new countryside construction:

Most of us know this strategy from various $T V$ news reports. Indeed, these typical villages reported on TV developed well. They tried hard and made it. However, they must have got various supports such as projects and money from the government. They need the government and the government needs them too. The local officials could overstate the results they have achieved, that is, a typical model of building new countryside within their domain. I do not think this is a good phenomenon.

During the village interview in Shuanghe, groups of villagers noted that lack of government support, pioneers and local enterprises was the primary restrictions of building a new countryside. When talking about how to build a new countryside, village head and villagers still want to attract investment, which may offer dozens of employment opportunities. Apparently, villagers are the main body in building a new countryside, and their ability may directly affect the pace of rural economy. However, Shuanghe Village has been suffered from depopulation and aging seriously. According to Table $1,51.87 \%$ of the rural population has migrated outside the township and village permanently or temporarily. Of all the 129 people stayed at the village: 35 people were pure farmers solely relied on agriculture with an average age about 56; 9 people were off-farm workers in 
local enterprises of Shuanghe, and their education level was just primary school; 16 people were individual enterprisers mainly involved in transportation industry or quartz-sand exploitation in the township. In addition, there were 34 elderly people with age 60 and above lived in the village and 16 of them were still involved in agricultural production. Affected by young and middle aged villagers' outmigration, age structure of village resident population became unreasonable (Figure 5). The proportion of people aged 60 and above and aged 65 and above in rural China was $14.49 \%$ and $9.79 \%$ in 2008 , respectively, which were much higher than the international criteria for aging society ( $10 \%$ and $7 \%$, respectively), and this means rural China became aging society. It was more shocking that, these two proportions of resident population in Shuanghe swelled to $26.36 \%$ and $17.05 \%$, respectively. It is also worth mentioning that, the out-migration also brought about longterm negative impact on the next generation. According to our investigation, the amount of leftbehind children and second child reached 19 and 15 , accounted for $38 \%$ and $30 \%$ of the 50 children with age between $0-15$, respectively. Due to lack of family care and guidance, these children' work at school was under average in most cases. Aging, with low education level and lack of professional skills were common features of residential people in Shuanghe Village, thus restricted the village's ability of realizing catch-up development.

In summary, Shuanghe Village suffered from accelerating out-migration of young and middle- aged labor forces and consequent aging problem, which could have just been called 'rural hollowing' or 'village hollowing' (Liu et al. 2010; Long et al. 2012), thus is now facing a serious shortage of capacity and motivation on transformation and development. While, since local government emphasized more on developed towns and villages during the course of building new countryside, the village was marginalized. New countryside construction in Shuanghe Village bogged down.

\section{Discussion}

Shuanghe Village's experiences showed that local responses to recent regional/rural policies have brought about unintended negative effects on socio-economic, resources and the environment. It is necessary to reveal the mechanism of these responses. In general, regionalized rural development is grounded in and driven by complex sets of internally and externally generated interrelationships and interactions from various rural developmental actors, and thus they are called "unfolding rural webs" vividly (Marsden 2010). These webs shape the relative attractiveness and competitiveness of rural spaces economically, socially, culturally and environmentally (Murdoch 2000; Marsden 2010). Actors are essential and decisive factor in rural development (Lakshmanan 1982; Terluin 2003; Binns and Nel 2003; Phuthego and Chanda 2004; Zhou and Liu 2008), and thus it must be kept in mind that the perspectives of these
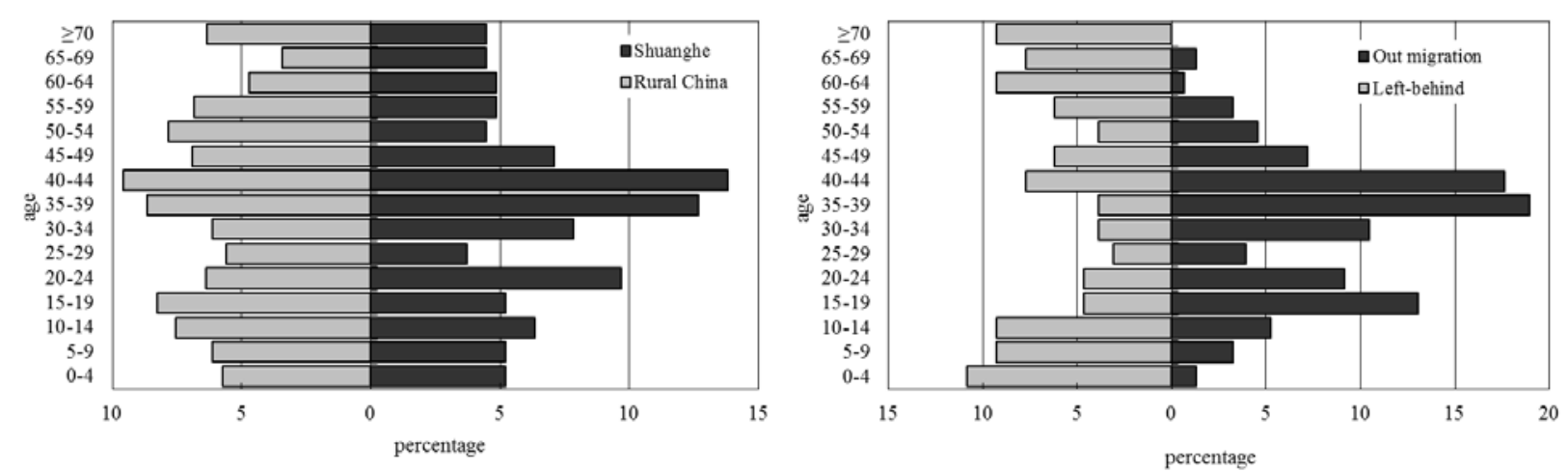

Figure 5 Population age structure diagrams of rural China and Shuanghe Village (Source: DPES-NBSC (2009) and author's survey)

Notes: Left, people of rural China and Shuanghe; right, out-migration and left-behind people of Shuanghe. The percentage of registered population that is of working age (customarily ages 15-64) in Shuanghe is $74.25 \%$, a little higher than that in rural China (70.81\%). But when considering the out-migration pattern, the percentage of left-behind population that is of working age in Shuanghe is $53.49 \%$, much lower than that of out-migrated population (88.89\%). 
actors involved in the implementation of rural development policies and strategies differ in terms of orientations and aspirations (Leeuwis 2000). Regional/rural policies would be successful only if a compromise can be worked out among the central government' agenda and other actors' needs.

Central government, local government, village cadres, and villagers are main actors concerning rural development in this case study. Apparently, the perspectives of central government on regional and rural development have been in transition since 1999, which have turned to promoting the balanced regional and urban-rural development and most consistent with local villagers. In terms of local government, the agent of central government and the protagonist of translating central government's policies and laws into practice generally, however, did not always have common objectives with central government, especially since the reform of the fiscal decentralization system. This system entices local government officials to strive for local economic growth in their terms of official to cater to the party/state's imperfect promotion/evaluation system and gain extra-budgetary revenues (Oi 1995; Zhou 2006; Tao and $\mathrm{Xu}$ 2007; Yang and Wang 2008), thus caused unintended consequences for current macro policy transition. For example, the local government implemented the WDP positively, and showed much passion in land acquisition and scramble for investment, through which they could get immediate economic growth and local fiscal revenue, and thus be more competitive in promotion/evaluation, though this may be at the cost of excessive farmland loss and local environment pollution. While during the implementation of GGP, because of the high monitoring cost of central government, local government was more prone to being involved in rent seeking (Xing 2008). After the tax-for-fee reform and the succedent abolition of agricultural taxes, it was found that the immediate result was a dramatic reduction in the autonomy of township governments as well as the provision of local services especially educational and medical services (Kennedy 2007; Gui 2008). Moreover, when implementing BNCS, they were inclined to invest in one or two developed towns and villages with much better economic base so that their investment and effort could work immediately and thus they could hand in beautiful answer sheet to higher levels of government as soon as possible.

Success stories of rural development confirmed that village cadres who have leadership, market vision, entrepreneurship and local complex played a key role in village transformation development (e.g. Binns and Nel 2003; Zhou and Liu 2008). However, Jiang's (2007) survey showed that most of the village cadres were incapable to promote village development. Similarly, Shuanghe's village cadres took no timely and effective action against outmigration, the GGP and consequent affluent forest resources. For example, they were absent for encouraging villagers to conduct farmland and forest land transfer so as to make full use of land resources and promote the development of scale management agriculture or local-based agro-food economy. As for the villagers, who should be the mainstay of building new countryside and promoting rural development (Terluin 2003; Ye 2005; Liu 2007; Long et al. 2010; Liu et al. 2011), they used to work hard but the majority of them chose to earn living outside the hometown in the 2000s. Moreover, the left-behind villagers, instead of taking advantage of affluent land resources and advantageous geographical location to practice local-based development, they intended to wait for, ask for and rely on local government's policy preferences with wishful thinking. As a result, ten years has passed, but like most of the surrounding villages, Shuanghe still failed to cast off poverty and set out on a road to prosperity.

As far as the four policies are concerned, they are all top-down design and central planned and lack strong place-based orientations, and thus significant regional differences are ignored in most times. For example, the per unit area agricultural production subsidies are the same in most counties. Moreover, WDP, GGP and ASPs are under the charge of the National Development and Reform Commission, the State Forestry Administration and the Ministry of Agriculture, respectively, while there is even no central sector responsible for BNCS. For lack of coordination mechanism, essential organic linkages between these policies are rare. Then it is not surprising that there are great difficulties in the integration of limited funds from various sectors to form a joint force and promote regional rural development. These 
centralized planning and implementation of uncoordinated one-size-fits-all policies are not sensitive to local contexts and circumstances, and thus failed to move the case study village from its historically marginal status.

Based on the above analysis, we argue that factors causing local villages' dilemmas include the nonuniformity of actors' objectives, finiteness of villagers' abilities, and the imperfect incentive and restraint mechanism for local government's activities under existing policy framework composed of uncoordinated one-size-fits-all policies. Hence, in order to optimize the local responses to macro socio-economic development policies, and thus to eliminate their negative effects on local socio-economic, resources and the environment, much effort should be made to optimize rural policies, coordinate the objectives of relative actors, increase the capacity of rural residents and restrain local government's behavior.

\section{Conclusion}

This paper explored local responses to four major macro socio-economic development policies and their effects on rural system, especially local resources and the environment based on a case study carried out in a typical mountainous village in southern Sichuan Province. The results show that the implementation of recent preferential policies has succeeded in offering new nonagricultural jobs which resulted in the income increase of off-farm workers and industrial development in cities and towns. However, the majority of villages have been further marginalized because local government emphasized much more on the already developed towns and villages during the course of building new countryside. As such the conventional villages are now facing increasingly difficulties in transforming traditional subsistence farming managed by aging labor forces to local agro-food economy and poor progress has been made in developing forest related eco-industry as well. Noteworthy, development zone fever and environment pollution have been spreading to less developed western rural China with weak land and environmental regulations. Overall, these new policies failed to promote the catch-up development of conventional villages and their ecological, economic and social sustainability were still unstable.

Fragile ecological environment, rich in natural resources and high incidence of poverty are currently common characteristics of China' mountainous areas (Chen 2006), and this determines that a more integrated and place-based rural policy needs to be developed (Woods 2005; Long et al. 2010). In order to pursue integrated and sustainable rural development in mountainous and less developed areas, the relationships between rural and urban, resources-environment and market, village and government and local and central government must be reevaluated, and thus the following issues need to be addressed. Firstly, local government's current way of seeking quick success and instant benefits should be scientifically examined. In party/state's promotion/evaluation system, indexes like farmland protection, environment protection, incidence of poverty, and income growth rate of low-income groups and so on should be given more weight. Secondly, household register system should be reformed in an orderly manner to give higher priority to registering rural migrant workers with stable jobs and permanent homes in cities or towns as permanent urban residents, and thus relieve the tension between rural population and local resource-environment system and increase per capita resource endowments. Thirdly, it is necessary and urgent to build villagers' capacity in less development villages to practice grassroots democracy, participatory rural planning and community-based development (Wang and Yao 2007). To regenerate the marginalized conventional villages, more consideration should be given to local-based and market-oriented agricultural product processing industry, and thus agriculture and rural areas would benefit more from the strengthened agro-food chain (Nel et al. 2007; Marsden 2010). As a premise, villagers should be empowered and encouraged to make full use of the affluent forestland resources and build new forest economy sustainably. In terms of the sources of funding, we suggest that government conduct experiments in selected counties or towns to integrate existing ASPs related financial fund which used to be distributed to each rural households but make no sense, and to establish a new fund mechanism aiming at supporting 
community-based public infrastructure construction or local industrial development projects. Fourthly, central villages/towns (CVTs) could be the main front of the new countryside construction and the focal point of rural urbanization in western China. Land supply could play an important role in adjustment of environmental-friendly industrial structure and urban-rural spatial restructuring and translating the land management, environmental protection and urbanization policies into an optimized industrial distribution and land-use pattern ( $\mathrm{Li}$ et al. 2011).

As for the approaches and policies of rural development in recent China, they should increasingly recognize the diversity of rural space and focus more on regions instead of one sector and aim to invest in new sources of competitive advantage instead of subsidies. Given different social, historical and cultural contexts makes generic policy implementation much difficult, they need to be flexible, place-based, supportive and coordinated. The transition from a sectoral to a territorial policy approach, including attempts to improve coordination and integration of the various sectoral policies at regional and local levels is in urgent need. Moreover, in order to ensure that all such policies can contribute to the overarching goals, great efforts should be made to improve central coordination of these policies through institutional arrangements for interministerial and interdepartmental coordination.

\section{References}

Baslé M (2006) Strengths and weaknesses of European Union policy evaluation methods: ex-post evaluation of Objective 2, 1994-99. Regional Studies 4O(2):225-235. DOI: 10.1080/ 00343400600600595

Binns T, Nel E (2003) The village in a game park: local response to the demise of coal mining in KwaZulu-Natal, South Africa. Economic Geography 79(1): 41-66. DOI: 10.1111/j.19448287.2003.tboo201.x

Bridger JC, Theodore RA (2008) An interactional approach to place-based rural development. Community Development 39(1): 99-111. DOI:10.1080/15575330809489744

Cai F (2011) Hukou system reform and unification of ruralurban social welfare. China \& World Economy 19(3): 33-48. DOI: 10.1111/j.1749-124X.2011.01241.X

Cao SX, Xu HG, Chen L, Wang XQ (2009) Attitudes of farmers in China's northern Shaanxi Province towards the land-use changes required under the Grain for Green Project, and implications for the project's success. Land Use Policy 26(4):
Our village-scale case study evaluated the local responses to four major macro socio-economic development policies and consequence effects on rural system, and further revealed that different rural developmental actors have different needs and objectives, which may directly affect their decisions on rural development. Therefore, more detailed comparative case studies in different types of rural areas need be carried out to further reveal the dynamic mechanism of resources and environment effects and recognize the objectives and decision-making mechanism of different rural developmental actors, and thus contribute to policy optimization and institutional innovation in the new period. Meanwhile, our field investigations partly revealed the serious depopulation and aging phenomenon in less developed rural areas of western China, detailed studies focus on its scale and impacts on human-land relationships of regional rural system and corresponding countermeasures are in urgent need.

\section{Acknowledgements}

This work was supported by the National Natural Science Foundation of China (Grant Nos. 41201176, 41130748 and 41171149) and China Postdoctoral Science Foundation (Grant Nos. 2011M500029 and 2012T50126). Special thanks are given to the anonymous reviewers for their constructive suggestions.
1182-1194. DOI: 10.1016/j.landusepol.2009.02.006

Chen GJ (2006) The trend and main task of study on the development of mountain areas in China. Journal of Mountain Science 24(5): 531-538. (In Chinese)

Chen MJ, Zheng YN (2008) China's regional disparity and its policy responses. China \& World Economy 16(4): 16-32. DOI: 10.1111/j.1749-124X.2008.00119.x

Courtney P, Hill G, Roberts D (2006) The role of natural heritage in rural development: an analysis of economic linkages in Scotland. Journal of Rural Studies 22(4): 469-484. DOI: 10.1016/j.jrurstud.2006.02.003

DPES-NBSC (Department of Population and Employment Statistics - National Bureau of Statistics of China) (2009) China Population and Employment Statistics Yearbook. Beijing: China Statistics Press.

Goodman DSG (2004) The campaign to "Open up the West": national, provincial-level and local perspectives. The China Quarterly 178: 317-334. DOI:10.1017/So305741004000190 
Grosjean P, Kontoleon A (2009) How sustainable are sustainable development programs? The case of the Sloping Land Conversion Program in China. World Development 37(1): 268-285. DOI:10.1016/j.worlddev.2008.05.003

Gui L (2008) Problems and countermeasures of grass-root finance after the abolition of agricultural tax in Western China. Rural Economy 8: 62-65. (In Chinese)

Huang JK, Wang XB, Zhi HY, et al. (2011) Subsidies and distortions in China's agriculture: evidence from producerlevel data. Australian Journal of Agricultural and Resource Economics 55(1): 53-71. DOI: 10.1111/j.1467-8489.2010. 00527.X

Jiang YS (2007) Main content and priority of building a new countryside in west china: an analysis based on questionnaires and group interviews of 387 village party secretary of Sichuan Province. Chinese Rural Economy 1: 2027. (In Chinese)

Kennedy JJ (2007) From the tax-for-tee reform to the abolition of agricultural taxes: the impact on township governments in north-west China. The China Quarterly 189: 43-59. DOI: 10.1017/So305741006000798

Kwieciński A, van Tongeren F (2007) Quantitative evaluation of a decade of agricultural policies in China: 1995-2005, Contributed Paper, International Agriculture Trade Research Consortium Symposium, Beijing.

Lakshmanan TR (1982) A systems model of rural development. World Development 10(10): 885-898. DOI: 10.1016/0305750X(82)90063-8

Leeuwis C (2000) Reconceptualizing participation for sustainable rural development: Towards a negotiation approach. Development and Change 31(5): 931-959. DOI: 10.1111/1467-7660.00184

Li XJ, Qiao JJ (2001) County level economic disparities of China in the 1990s. Acta Ceographica Sinica 56(2): 136-145. (In Chinese)

Li YR, Long HL, Liu YS (2010) Industrial development and land use/cover change and their effects on local environment: a case study in Changshu in eastern coastal China. Frontiers of Environmental Science and Engineering in China 4(4): 438448. DOI: $10.1007 / \mathrm{s} 11783-010-0273-3$

Li YR, Wei DYH (2010) The spatial-temporal hierarchy of regional inequality of China. Applied Geography 30(3): 303316. DOI:10.1016/j.apgeog.2009.11.001

Lin JH, Ren BP (2009) Evaluation of Western Development Program: 1999-2008. Research on Development 1: 48-52. (In Chinese)

Liu JG, Li SX, Ouyang ZY, et al. (2008) Ecological and socioeconomic effects of China's policies for ecosystem services. Proceedings of the National Academy of Sciences of the United State of America 105(28): 9477-9482. DOI: 10.1073/pnas.0706436105

Liu YS (2007) Rural transformation development and new countryside construction in eastern coastal area of China. Acta Ceographica Sinica 62(6): 563-570. (In Chinese)

Liu YS, Chen YF, Long HL (2011) Regional diversity of peasant household response to new countryside construction based on field survey in eastern coastal China. Journal of Geographical Sciences 21(5): 869-881. DOI: 10.1007/s11442-011-0886-x

Liu YS, Liu Y, Chen YF, Long HL (2010) The process and driving forces of rural hollowing in China under rapid urbanization. Journal of Geographical Sciences 20(6): 876-888. DOI: 10.1007/s11442-010-0817-2

Long HL, Li YR, Liu YS, et al. (2012) Accelerated restructuring in rural China fueled by "increasing vs. decreasing balance" land-use policy for dealing with hollowed villages. Land Use Policy 29(1): 11-22. DOI:10.1016/j.landusepol.2011.04.003

Long HL, Liu YS, Li XB, Chen YF (2010) Building new countryside in China: a geographical perspective. Land Use Policy 27(2): 457-470. DOI:10.1016/j.landusepol.2009.o6. 006

Long HL, Woods M (2011) Rural restructuring under globalization in eastern coastal China: What can be learned from Wales? Journal of Rural and Community Development 6(1): 70-94.

Long HL, Zou J, Pykett J, Li YR (2011) Analysis of rural transformation development in China since the turn of the new millennium. Applied Geography 31(3): 1094-1105. DOI:10.1016/j.apgeog.2011.02.006

Marsden $\mathrm{T}$ (2010) Mobilizing the regional eco-economy: evolving webs of agri-food and rural development in the UK. Cambridge Journal of Regions, Economy and Society 3(2): 225 -244. DOI:10.1093/cjres/rsq010

McNally CA (2004) Sichuan: Driving capitalist development westward. The China Quarterly 178: 426-447. DOI: 10.1017/So305741004000244

Midmore P, Langstaff L, Lowman S, Vaughan A (2008) Qualitative evaluation of European rural development policy: Evidence from comparative case studies. 12th Congress of the European Association of Agricultural Economics - EAAE 2008, Ghent, Belgium.

Midmore P, Partridge MD, Olfert MR, Ali K (2010) The evaluation of rural development policy: macro and micro perspectives. EuroChoices 9(1): 24-28. DOI: 10.1111/j.1746692X.2010.00155.x

Murdoch J (2000) Networks: a new paradigm of rural development? Journal of Rural Studies 16(4): 407-419. DOI: 10.1016/So743-0167(00)00022-X

NDRC (National Development and Reform Commission) (2005, 2009) China Agricultural Products Cost-benefit Compilation of Information. Beijing: China Statistics Press.

Nel E, Binns T, Bek D (2007) 'Alternative foods' and community-based development: Rooibos tea production in South Africa's West Coast Mountains. Applied Geography 27(2): 112-129. DOI:10.1016/j.apgeog.2006.11.001

OECD (2003) The future of rural policy: from sectoral to placebased policies in rural areas. OECD.

OECD (2005) Place-based policies for rural development: provinces of Arezzo and Grosseto, Tuscany, Italy. OECD.

Oi JC (1995) The role of the local state in China's transitional economy. The China Quarterly 144: 1132-1150. DOI: 10.1017/So305741000004768

Olfert MR, Partridge MD (2010) Best practices in twenty-firstcentury rural development and policy. Growth and Change 41(2): 147-164. DOI: 10.1111/j.1468-2257.2010.00523.x

Partridge MD, Rickman DS (2006) The Geography of American Poverty: Is There a Need for Place-Based Policies?. Kalamazoo, MI: W.E. Upjohn Institute for Employment Research.

Pezzini M (2001) Rural policy lessons from OECD countries. International Regional Science Review 24(1): 134-145. DOI: 10.1177/016001701761013024

Phuthego TC, Chanda R (2004) Traditional ecological knowledge and community-based natural resource management: lessons from a Botswana wildlife management area. Applied Geography 24(1): 57-76. DOI:10.1016/ j.apgeog.2003.10.001

Psaltopoulos D, Thomson KJ, Efstratoglou S, Kola J, Daouli A (2004) Regional social accounting matrices for structural policy analysis in lagging EU. European Review of Agricultural Economics 31(2): 149-178. DOI: 10.1093/erae/ 31.2.149

Ravallion M, Wodon QT (1999) Poor areas, or only poor people? Journal of Regional Science 39(4): 689-711. DOI: 10.1111/0022-4146.00156

Ryser L, Halseth G (2010) Rural economic development: A review of the literature from industrialized economies. Geography Compass 4(6): 510-531. DOI: 10.1111/j.17498198.2010.00321.x

Tao R, Xu ZG (2007) Urbanization, rural land system and social security for migrants in China. Journal of Development Studies 43(7): 1301-1320. DOI:10.1080/00220380701526659

Terluin IJ, Roza P (2010) Evaluation methods for rural development policy. Report 2010-037. April 2010. LEI, part of Wageningen UR. The Hague. 
Terluin IJ (2003) Differences in economic development in rural regions of advanced countries: an overview and critical analysis of theories. Journal of Rural Studies 19(3): 327-344. DOI: 10.1016/So743-0167(02)ooo71-2

Tian SQ, Huang YH (2010) Evaluation of Western Development Program: a urban-rural income gap perspective. Inquiry into Economic Issues 9: 20-25. (In Chinese)

Trac CJ, Harrell S, Hinckley TM, Henck AC (2007) Reforestation programs in southwest China: reported success, observed failure, and the reasons why. Journal of Mountain Science 4(4): 275-292. DOI: 10.1007/s11629-007-0275-1

Uchida E, Xu JT, Rozelle S (2005) Grain for Green: costeffectiveness and sustainability of China's Conservation SetAside Program. Land Economics 81(2): 247-264. DOI: 10.3368/le.81.2.247

Wang LL, Wei HK (2004) Progress of western China development drive, and evaluation of the results. China \& World Economy 12(2): 20-33.

Wang SN, Yao Y (2007) Grassroots democracy and local governance: evidence from rural China. World Development 35(10): 1635-1649. DOI: 10.1016/j.worlddev.2006.10.014

Wei YHD, Ye X (2009) Beyond convergence: space, scale, and regional inequality in China. Tijdschrift voor Economische en Sociale Geografie 100(1): 59-80. DOI: 10.1111/j.14679663.2009.00507.x

Woods M (2005) Rural Geography: Processes, Responses and Experiences in Rural Restructuring. London: Sage.

Xing ZL (2008) The rent-seeking in the implementation of Grain for Green Project: a case study in Neijiang city of Sichuan Province. China Rural Survey 3: 29-37. (In Chinese)

Xu JY, Chen LD, Lu YH, Fu BJ (2007) Sustainability evaluation of the Grain for Green Project: From local people's responses to ecological effectiveness in Wolong Nature Reserve. Environmental Management 40: 113-122. DOI: 10.1007/s00267-006-0113-1

$\mathrm{Xu} \mathrm{W,} \mathrm{Tan} \mathrm{KC} \mathrm{(2002)} \mathrm{Impact} \mathrm{of} \mathrm{reform} \mathrm{and} \mathrm{economic}$ restructuring on rural systems in China: a case study of Yuhang, Zhejiang. Journal of Rural Studies 18(1): 65-81. DOI: 10.1016/So743-0167(01)00030-4

Yang DT, Li YF (2008) Agricultural price reforms in China: experience from the past three decades. Agroalimentaria, 27: 13-23

Yang DYR, Wang HK (2008) Dilemmas of local governance under the development zone fever in China: a case study of the Suzhou region. Urban Studies 45(5-6): 1037-1054. (DOI: 10.1177/0042098008089852)

Yao HQ, Ren ZZ (2009) Blue Book of Western Region of China: Annual Report on Economic Development in Western Region of China. Beijing: Social Sciences Literature Publishing House. (In Chinese)

Ye JZ (2005) Construction of the New Countryside: Farmers' Perspectives. Beijing: Social Sciences Literature Publishing House. (In Chinese)

Yeung YM, Shen JF (2004) Developing China's West: A Critical Path to Balanced National Development. Hong Kong: Chinese University Press.

Yin RK (1994) Case Study Research. Sage, Thousand Oaks, CA.

Ying LG (2003) Understanding China's recent growth experience: a spatial econometric perspective. Annals of Regional Science 37(4): 613-628. DOI: 10.1007/so0168-0030129-x

Yu WS, Hans GJ (2010) China's agricultural policy transition: impacts of recent reforms and future scenarios. Journal of Agricultural Economics 61(2): 343-368. DOI: 10.1111/j.14779552.2010.00242.x

Zhou FZ (2006) A decade of tax-sharing: the system and its evolution. Social Sciences in China 6: 100-115. (In Chinese)

Zhou LB, Liu KB (2008) Community tourism as practiced in the mountainous Qiang region of Sichuan Province, China: a case study in Zhenghe Village. Journal of Mountain Science 5(2): 140-156. DOI: $10.1007 / \mathrm{s} 11629-008-0098-8$ 